\title{
Research of Synchronous Jacking up Construction Monitoring and Control Technologies of Bridge
}

\author{
Jia $\mathrm{He}^{1, \mathrm{a}}$, Xingzan $\mathrm{Gao}^{2, \mathrm{~b}}$ \\ ${ }^{1}$ College of civil engineering \& architecture, China Three Gorges University, No. 8 University Road in \\ Yichang, China \\ ${ }^{2} \mathrm{Hu}$ Bei Expressway Industrial Development CO., LTD, No. 9 Long Yang Road in Han yang District \\ in Wuhan, China \\ a244037253@qq.com, bgaoxingzan@qq.com
}

Key words: Synchronous Jacking up, Monitoring and Control, Simulation

Abstract:This study is to optimize the longitudinal linear of the original route based on the jacking up construction of one bridge in the Xiamen-Chengdu Expressway project, which applied the synch ronous jacking up construction method to raise the beam and consequently achieve the designed lin ear. Through the research of the jacking up technology, the synchronous jacking up construction mo nitoring and control technologies during the whole process of the construction as well as simulate th e limit force of the beam by means of finite element software, the accurate analyzing threshold coul $\mathrm{d}$ be offered to the monitoring step.

\section{Introduction}

The bridge has a full length of 38 meters, and the superstructure is made up of preset hollow beams under 2 holes $(16 \mathrm{~m})$, which is simple supported at first and then with continuous deck. The substructure is made up of double-column piers and bored pile foundation. Rectangular laminated rubber bearing is also being applied. In order to optimize the longitudinal linear of the original route, so that the bridge's operational carrying capacity will not be affected, the bridge is heightened. All in all, a Jacking up method will be used on this bridge, and the height of Jacking up method depends on how much the bridge demands to be raised.

\section{Program Design}

Jacking up Program. This bridge uses a Steel Corbel staged jacking up program, and the jacking up schematic diagram is like Figure 1 [1]. A jack that can initiate jacking force is installed in every support vertex, and the structure is jacked up by controlling the hydraulic pump drive through the console. When it comes to the projected height in each stage, the beam is fixed by temporary pads or spacers. After the jacks are raised, the jacking up work will move on to stage two. This cycle is repeated until the structure is raised to the designed height. 


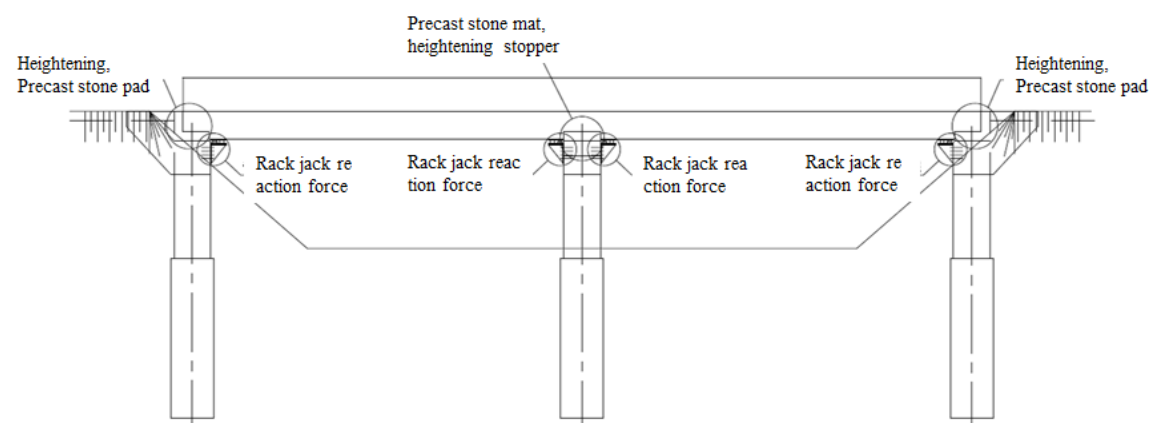

(a) Longitudinal sketch map

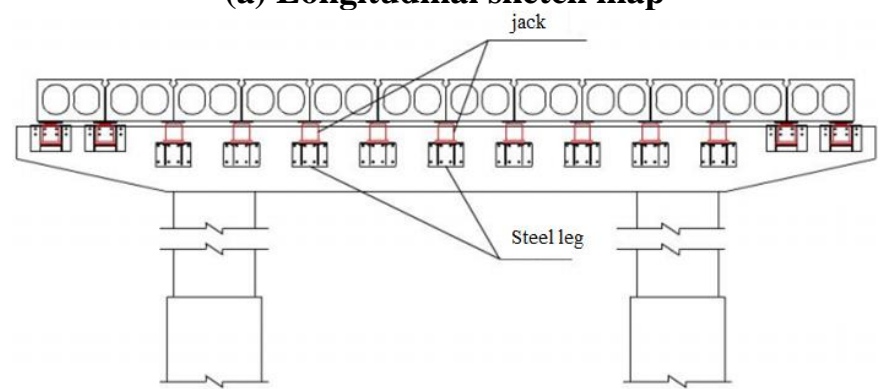

(b) Horizontal sketch map

Fig. 1 bridge type steel bracket lifting diagram

The Calculation of Support Reaction Force. The maximum support reaction force of each bearing is calculated based on the beam's constant load(Weight + Pavement), and the result should take some margin into consideration. The tonnage of the jacks should be deployed no less than 1.5 times of the calculated value [2].

Jacking up Construction Process. The process of Jacking up Construction [3] is shown as the Figure 2.

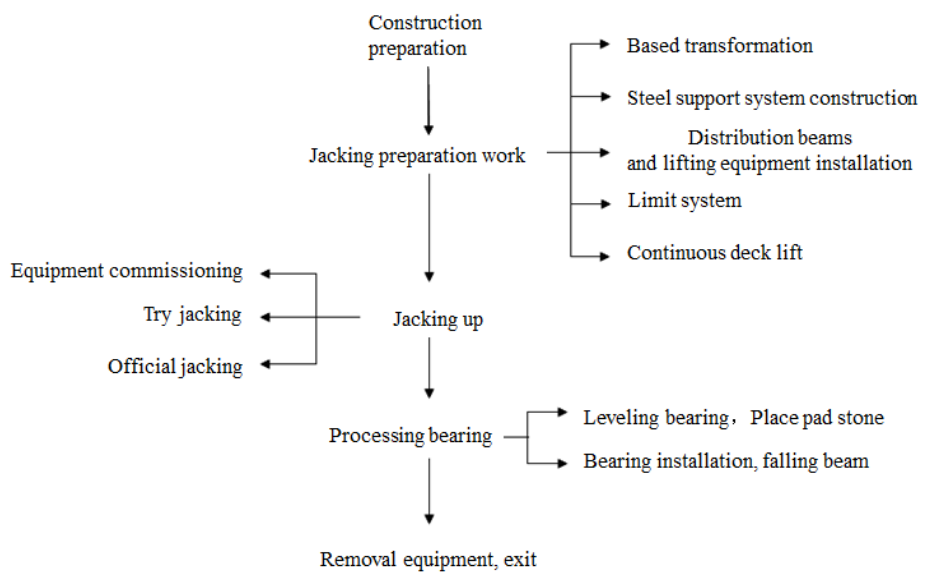

Fig. 2 The construction flow chart of jacking of beam

\section{Jacking up Construction Technology}

Placement of the Jack and Temporary Support. Because the designed hollow beam bottom thickness is poor, the jack and temporary support are placed at the beam bottom of the hollow webs, and a $0.30 \times 0.30 \mathrm{~m} 2$ steel plate is placed to prevent the beam bottom from concentrated force, which is shown as the Figure 3. 


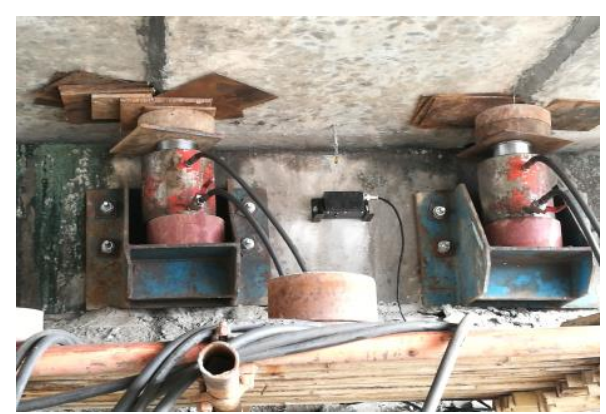

Fig.3 Arrangement of jacking of $0 \#$ abutment 、 temporary block and wire drawing sensor

\section{Try jacking}

Before the formal jacking, after all of the related constraints are removed, try a $5 \mathrm{~mm}$ jacking up at first. Through setting different lifting speed, which is increased from $0.1 \mathrm{~mm} / \mathrm{min}$ to $0.5 \mathrm{~mm} /$ min, and then lock the pilot valve to maintain the cylinder pressure and hold the pressure for 20 minutes.

Formal Jacking. The whole route of $158 \mathrm{~mm}$ is divided into 2 stages. When the beam is jacked up into the designed height in each stage, keep the jack's oil pressure unchanged and install the temporary support. Then adjust the temporary support height to ensure the temporary support fits the beam bottom [4], and return the oil of hydraulic system and make the beam fixed on the temporary support at the same time. After the jacks are raised, the jacking up work will move on to the next stage, until the projected height is achieved [5]. The Drawing Sensor is used in the jacking system to control the lifting speed and height.

Sustained Load Stage Construction. After the jacking up is done, the whole load from the structure is transmitted to the jacks and temporary support. Scuttle the original pad stone and remove all the cement of the capping beam. Before the pad stone is placed, a 3-5mm layer of cement needs to be paved on the capping beam to level the surface, and ensure the top level. Install the new prefabricated support cushion stone, bearing, etc. to make sure the beam bearing contact closely and prevent void and partial pressure.

Synchronous Falling Beam Construction. After the bearings and pad stone are completely installed, and the hydraulic system oil returns, put down the beam slowly to the newly installed bearings, and transmit the superstructure load to the bearings. Reset the elevation of the beam top after the beam falling.

\section{Monitoring of Synchronous Jacking up Process}

Calculation of Safety Threshold during the Jacking Process of Beam. According to the design data, concrete $\mathrm{C} 40$ is used for hollow slab beam of bridge, and section design uses $16 \mathrm{~m}$ span general drawings promulgated by the Ministry of Communications "superstructure of assembled post tensioning prestressed concrete simply supported hollow slab bridge" [6]. Model constraints consider the continuous lifting of the bridge, and one side slide, the other is fixed. Taking the middle beam as an example, a single beam solid mesh model is built by the software FEA Midas, which is shown in Figure 4.

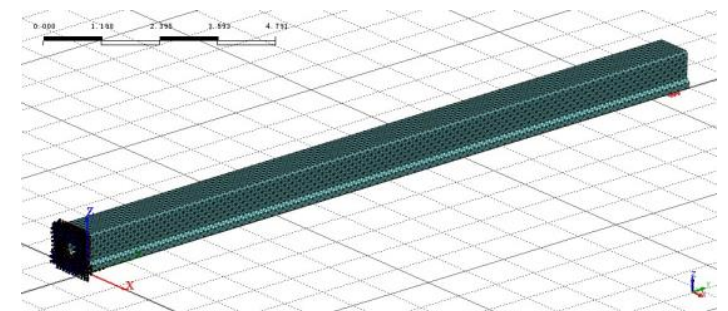

Fig. 4 Single beam solid mesh model

In order to simulate the displacement on both sides of the fulcrum during jacking, sliding end is given a certain amount of forced displacement. Through the comparison of tensile stress value of 
concrete on the surface of the beam and design value of tensile strength of concrete, two fulcrum maximum displacement difference threshold is determined. The calculation results are shown in Table 1.

Tab. 1 The maximum tensile stress of the beam under different forced displacement of the single beam model

\begin{tabular}{c|c|c|c|c}
\hline $\begin{array}{c}\text { Serial } \\
\text { number }\end{array}$ & $\begin{array}{c}\text { Forced displacement } \\
\text { /mm }\end{array}$ & $\begin{array}{c}\text { Maximum tensile stress of } \\
\text { concrete beam/ MPa }\end{array}$ & $\begin{array}{c}\text { Design value of tensile } \\
\text { strength of concrete/ MPa }\end{array}$ & $\begin{array}{c}\text { Cracking or not } \\
\text { of concrete }\end{array}$ \\
\hline 1 & 1 & 1.089 & & no \\
\hline 2 & 2 & 1.200 & & no \\
\hline 3 & 3 & 1.312 & \multirow{2}{*}{1.65} & no \\
\hline 4 & 4 & 1.423 & & no \\
\hline 5 & 5 & 1.535 & & no \\
\hline 6 & 6 & 1.646 & & yes \\
\hline
\end{tabular}

Jack monitoring content. Controlling the security of structure is the main goal of jacking process, monitoring early warning should be controlled by a number of indicators. Early warning is needed as long as there is an excessive. Jacking construction monitoring index and monitoring content are gathered in Table 2.

Tab.2 Jacking construction monitoring index and monitoring content table

\begin{tabular}{|c|c|c|c|c|c|c|}
\hline $\begin{array}{c}\text { Serial } \\
\text { number }\end{array}$ & Monitoring index & $\begin{array}{c}\text { Frequency of } \\
\text { monitoring }\end{array}$ & $\begin{array}{l}\text { Location of } \\
\text { monitoring } \\
\text { points }\end{array}$ & $\begin{array}{c}\text { Monitoring } \\
\text { content }\end{array}$ & $\begin{array}{c}\text { Early } \\
\text { warning } \\
\text { value }\end{array}$ & $\begin{array}{l}\text { Instrument } \\
\text { and } \\
\text { equipment }\end{array}$ \\
\hline 1 & Deck elevation & $\begin{array}{c}\text { 3/pier } \\
\text { (abutment) }\end{array}$ & $\begin{array}{l}\text { Upper part of } \\
\text { beam end }\end{array}$ & $\begin{array}{c}\text { Elevation } \\
\text { difference of } \\
\text { fulcrum }\end{array}$ & $5 \mathrm{~mm}$ & Level \\
\hline 2 & $\begin{array}{l}\text { Bridge center } \\
\text { line }\end{array}$ & $2 /$ set & $\begin{array}{l}\text { Upper part of } \\
\text { beam end }\end{array}$ & $\begin{array}{c}\text { Deviate } \\
\text { from } \\
\text { center line } \\
\end{array}$ & $5 \mathrm{~mm}$ & Steel ruler \\
\hline 3 & $\begin{array}{c}\text { Longitudinal } \\
\text { displacement of } \\
\text { beam }\end{array}$ & $4 /$ set & $\begin{array}{l}\text { Upper part of } \\
\text { beam end }\end{array}$ & $\begin{array}{c}\text { Relative } \\
\text { displacement }\end{array}$ & $10 \mathrm{~mm}$ & Steel ruler \\
\hline 4 & $\begin{array}{l}\text { Stress and strain } \\
\text { at the bottom of } \\
\text { the beam }\end{array}$ & $\begin{array}{l}3 \text { pieces of } \\
\text { beam/span }\end{array}$ & $\begin{array}{l}\text { Fulcrum of } \\
\text { beam bottom }\end{array}$ & $\begin{array}{c}\text { Deformation } \\
\text { of beam }\end{array}$ & $33 \mu \varepsilon$ & $\begin{array}{c}\text { Surface } \\
\text { mount type } \\
\text { strain sensor } \\
\end{array}$ \\
\hline 5 & $\begin{array}{l}\text { Cracks in the } \\
\text { bottom of the } \\
\text { beam }\end{array}$ & $\begin{array}{l}\text { According } \\
\text { to the scene }\end{array}$ & Beam bottom & $\begin{array}{l}\text { Width of } \\
\text { cracks }\end{array}$ & $\begin{array}{c}\text { Limits of } \\
\text { specification }\end{array}$ & $\begin{array}{c}\text { Crack width } \\
\text { sensor }\end{array}$ \\
\hline
\end{tabular}

Monitoring results of beam body before and after Jacking up. Monitoring results of displacement change:

Before and after jacking up the variety of deck elevation are shown in Table 3.

Tab.3 The elevation change of beam before and after jacking up

\begin{tabular}{c|c|c|c|c|c|c}
\hline $\begin{array}{c}\text { Number } \\
\text { of } \\
\text { measuring } \\
\text { point }\end{array}$ & $\begin{array}{c}\text { Position of } \\
\text { measuring } \\
\text { point }\end{array}$ & $\begin{array}{c}\text { Actual } \\
\text { displacement } \\
\text { of } \\
\text { synchronous } \\
\text { jacking } \\
/ \mathrm{mm}\end{array}$ & $\begin{array}{c}\text { Actual } \\
\text { displacement of } \\
\text { synchronous } \\
\text { falling beam in } \\
\text { the first stage } \\
/ \mathrm{mm}\end{array}$ & $\begin{array}{c}\text { Actual } \\
\text { displacement } \\
\text { of synchronous } \\
\text { falling beam in } \\
\text { the second } \\
\text { stage } \\
/ \mathrm{mm}\end{array}$ & $\begin{array}{c}\text { Elevation of } \\
\text { beam body after } \\
\text { replacement of } \\
\text { cushion stone } \\
\text { and support } \\
/ \mathrm{mm}\end{array}$ & $\begin{array}{c}\text { Difference } \\
\text { of deck } \\
\text { elevation } \\
/ \mathrm{mm}\end{array}$ \\
\hline 1 & $\begin{array}{c}\text { Left side of } \\
\text { 0\# abutment }\end{array}$ & 158.0 & 85.4 & 72.8 & 158.2 & 0.2 \\
\hline 2 & $\begin{array}{c}\text { Middle of 0\# } \\
\text { abutment }\end{array}$ & 158.0 & 85.7 & 72.4 & 158.1 & 0.1 \\
\hline 3 & Right side of & 158.0 & 85.9 & 72.3 & 158.2 & 0.2 \\
\hline
\end{tabular}




\begin{tabular}{c|c|c|c|c|c|c}
\hline & 0\# abutment & & & & & \\
\hline 4 & $\begin{array}{c}\text { Left side of } \\
\text { 1\# pier }\end{array}$ & 158.0 & 85.9 & 72.4 & 158.3 & 0.3 \\
\hline 5 & $\begin{array}{c}\text { Middle of 1\# } \\
\text { pier }\end{array}$ & 158.0 & 85.5 & 72.6 & 158.1 & 0.1 \\
\hline 6 & $\begin{array}{c}\text { Right side of } \\
\text { 1\# pier }\end{array}$ & 158.0 & 85.7 & 72.5 & 158.2 & 0.2 \\
\hline 7 & $\begin{array}{c}\text { Left side of } \\
\text { 2\# abutment }\end{array}$ & 158.0 & 85.4 & 72.8 & 158.2 & 0.2 \\
\hline 8 & $\begin{array}{c}\text { Middle of 2\# } \\
\text { abutment }\end{array}$ & 158.0 & 85.5 & 72.7 & 158.2 & 0.2 \\
\hline 9 & $\begin{array}{c}\text { Right side of } \\
\text { 2\# abutment }\end{array}$ & 158.0 & 85.5 & 72.7 & 158.2 & 0.2 \\
\hline
\end{tabular}

Jacking height of adjacent jacking point of one pier is within $0.5 \mathrm{~mm}$ and jacking height of one beam is within $0.5 \mathrm{~mm}$, which meets the monitoring requirements.

The beam does not appear the situation of deviation of bridge center line during the process of jacking and falling beam.

The beam does not appear the situation of longitudinal displacement during the process of jacking and falling beam.

Monitoring results of stress and strain:

The maximum strain monitoring position is arranged at the jacking point according to the calculation results of finite element software. The same across both sides of the fulcrum jacking difference should be controlled within $5 \mathrm{~mm}$, the press should be $33 \mu \varepsilon$. The bridge Jacking (falling beam) beam strain Record is shown in Table 4.

Tab.4 Strain record table of the beam during jacking (falling)

\begin{tabular}{|c|c|c|c|c|c|c|c|c|c|c|}
\hline \multirow{2}{*}{ stage } & \multicolumn{3}{|c|}{ 0\#abutment strain $/ \mu \varepsilon$} & \multicolumn{3}{|c|}{$1 \#$ pier strain $/ \mu \varepsilon$} & \multicolumn{3}{|c|}{ 2\#abutment strain $/ \mu \varepsilon$} & \multirow{2}{*}{$\begin{array}{l}\text { Temper } \\
\text { ature } /{ }^{\circ} \mathrm{C}\end{array}$} \\
\hline & $1 \#$ & $2 \#$ & $3 \#$ & $1 \#$ & 2\# & $3 \#$ & $1 \#$ & $2 \#$ & 3\# & \\
\hline Initial Value0mm & 0 & 0 & 0 & 0 & 0 & 0 & 0 & 0 & 0 & 32.4 \\
\hline Jacking up5mm & 1 & 2 & 1 & 1 & 1 & 1 & 2 & 1 & 1 & 32.6 \\
\hline Jacking up $10 \mathrm{~mm}$ & 2 & 3 & 2 & 3 & 2 & 2 & 2 & 2 & 2 & 33.0 \\
\hline Jacking up $15 \mathrm{~mm}$ & 3 & 3 & 4 & 6 & 5 & 7 & 5 & 4 & 4 & 33.0 \\
\hline Jacking up 20mm & 3 & 4 & 6 & 6 & 5 & 7 & 5 & 4 & 4 & 33.0 \\
\hline Jacking up $50 \mathrm{~mm}$ & 3 & 4 & 4 & 6 & 5 & 6 & 4 & 4 & 4 & 33.1 \\
\hline $\begin{array}{l}\text { Falling beam of first stage } \\
86 \mathrm{~mm}\end{array}$ & 4 & 5 & 5 & 4 & 4 & 4 & 3 & 3 & 4 & 32.7 \\
\hline Jacking up 95mm & 5 & 4 & 4 & 3 & 3 & 2 & 2 & 2 & 3 & 32.1 \\
\hline Jacking up $110 \mathrm{~mm}$ & 5 & 4 & 4 & 3 & 2 & 3 & 1 & 2 & 2 & 32.0 \\
\hline Jacking up $135 \mathrm{~mm}$ & 6 & 3 & 2 & 2 & 2 & 2 & 1 & 2 & 2 & 32.0 \\
\hline $\begin{array}{l}\text { Falling beam of second } \\
\text { stage } 158 \mathrm{~mm}\end{array}$ & 4 & 3 & 3 & 3 & 2 & 2 & 1 & 2 & 1 & 32.1 \\
\hline
\end{tabular}

According to the result measured on site, the biggest strain value of the beam during synchronous Jacking up is $7 \mu \varepsilon$, which is far smaller than the theoretical limit of the control value, and the structure is safe

Crack change monitoring results:

There is no significant development of the beam crack and no emerge of new crack neither in jacking up process nor after falling.

\section{Conclusions}

- The jacking up construction uses a synchronous jacking up system, with each fulcrum position jacking up and falling at the same time. During the whole operation process, the height between to neighbor jacking points in the same abutment is within $0.5 \mathrm{~mm}$, and within $5.0 \mathrm{~mm}$ in the same beam, which meet the monitoring requirements.

- There is no significant development of the beam crack and no emerge of longitudinal and lateral 
offset of the beam neither in jacking up process nor after falling.

- The biggest strain value of the beam during synchronous Jacking up is $7 \mu \varepsilon$, which is far smaller than the theoretical limit of the control value, and the structure is safe.

- By using fine entity simulation software Midas/FEA to develop single beam entity grid model, we can simulate the limit force of the beam during jacking up precisely, and accurate analyzing threshold could be offered to the monitoring step.

\section{References}

[1] Shuhao Chen, Wuyang Ding etc. Xiamen-Chengdu expressway Zhanglong Longyan segment Cement Concrete Pavement Reconstruction Project bridge jacking rehabilitation programs [D]. Jiangsu Transportation Research Group Co., Ltd.2016. (In Chinese)

[2] Xinran Yu. Xiacaowan Bridge Synchronous Jacking up bearing replacement construction technology [J]. Highway, 2015, (4): 118-122. (In Chinese)

[3] JTG/T J23-2008. Echnical Specincations for Strengthening Construction of Highway Bridges [S]. Peking: people's communications publishing house, 2008. (In Chinese)

[4] Minghua Zhou, Ruixing Zhai. Highway bridge rubber bearing replacement technology is discussed [J]. Modern Transportation Technology, 2005 (3) : 52-54. (In Chinese)

[5] JTG/T J22-2008. Specincations for Strengthening Design of Highway Bridges [S].Peking: people's communications publishing house, 2008. (In Chinese)

[6] Committee of Experts of Ministry of Transport. People's Republic of China Transportation Industry General Photo of Highway Bridges-Fabricated post-tensioned concrete simply supported beam hollow slab upper structure. China Communications Press.2008. (In Chinese) 